\title{
Spark Plasma Sintering Technique and Application for All-Solid-State Batteries
}

\author{
Seokhee Lee ${ }^{\dagger}$ \\ Korea Institute of Ceramic Engineering and Technology, Jinju 52851, Korea \\ 전고상 전지를 위한 스파크 플라스마 소결 기술과 응용 \\ 이석희 ${ }^{\dagger}$ \\ 한국세라믹기술원
}

(Received May 24, 2019; Revised June 25, 2019; Accepted June 25, 2019)

\begin{abstract}
s
All-solid-state batteries have received increasing attention because of their high safety aspect and high energy and power densities. However, the inferior solid-solid interfaces between solid electrolyte and active materials in electrode, which cause high interfacial resistance, reduce ion and electron transfer rate and limit battery performance. Recently, spark plasma sintering is emerging as a promising technique for fabricating solid electrolytes and composite-electrodes. Herein, this paper focuses on the overview of spark plasma sintering to fabricate solid electrolytes and composite-electrodes for all-solid-state batteries. In the end, future opportunities and challenges associated with SPS technique for all-solid-state batteries are described.
\end{abstract}

Keywords: Spark Plasma Sintering, Solid Electrolytes, Composite-Electrode, Interface Stability, All-Solid-State Batteries

\section{1. 서론}

리튬 이온(Li-ion) 이차 전지는 에너지 및 전력 밀도가 상대적으로 높기 때문에 휴대용 기기나 전기 자동차와 같 이 광범위한 분야에서 에너지 저장 시스템으로 사용되어 왔다. ${ }^{1-2)}$ 그러나 액체 유기 전해질을 기반으로 하는 전통
적인 리튬 이온 이차 전지는 높은 에너지 밀도와 안정성, 빠른 충 - 방전 속도 및 저렴한 비용을 요구하는 자동차 산업의 요구를 충족시키는데 어려움이 있다. 특히, 이런 리튬 이온 이차 전지에 사용 되는 액체 전해질은 높은 휘 발성 및 가연성으로 인해 열에 의한 폭발에 따른 위험성 이 존재한다. ${ }^{3)}$ 따라서, 전고상 전지는 기존의 리튬 이온 
(a)

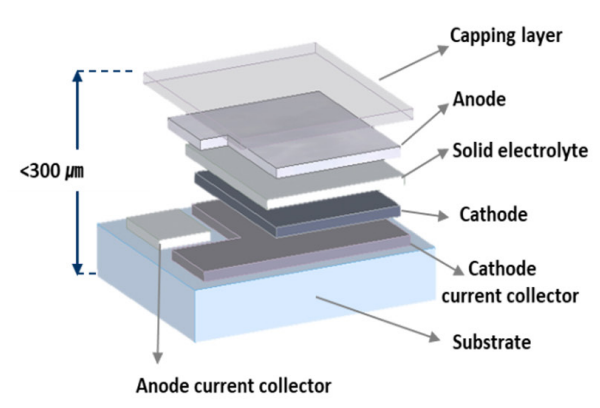

(b)

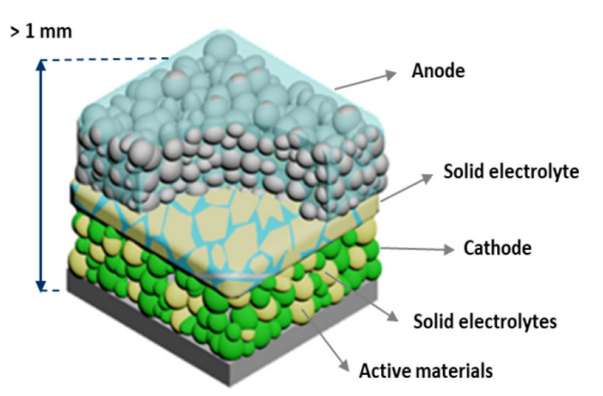

Fig. 1. 전고상 전지 유형. (a) 박막형 전고상 전지, (b) 벌크형 전고상 전지

이차 전지의 문제점을 극복하기 위해서 현재 많은 연구가 진행 중에 있다. ${ }^{4)}$ 전고상 전지에서 고체 전해질(solid electrolytes)은 리튬 이온 이차 전지에 사용되는 액체 전 해질을 대체하기 위해서 사용되는 핵심 구성 요소이다.5) 일반적으로, 전고상 전지는 두가지 유형인 박막형과 벌크 형이 있다. (Fig. 1) 박막형 전고상 전지 같은 경우는 전 극과 전해질을 박막 프로세스(PVD, CVD, and Thermal Evaporation)를 통해 다층형 구조를 가질 수 있어 전지 패키지의 무게와 부피를 줄이고, 전지의 에너지 밀도를 높일 수 있는 장점이 있다. ${ }^{6)}$ 그러나 이런 박막형 구조를 가지는 전고상 전지는 전극 두께가 얇아 전지가 가지는 용량이 낮은 문제점을 가지고 있다. 이런 문제점을 해결 하기 위해서 전극의 두께나 면적을 증가시켜야 하나 박막 프로세스의 한계 및 전극 내에서 이온과 전기 전도도의 문제로 현재 연구 개발은 박막형 보다 제조가 쉽고 전극 관련 기초연구에 적합한 벌크형 전고상 전지 연구에 많은 초점을 맞추고 있다. ${ }^{7-8)}$

전고상 전지에서 고체 전해질은 전극 복합체 (composite-electrodes)에서 이온 전도체와 두 전극을 분리하는 중요한 역할을 한다. 전고상 전지에서 고체 전 해질의 사용은 액체 전해질로 인한 위험을 제거할 뿐만 아니라 $\mathrm{Li}$ 금속을 전지 시스템에서 전극으로 채택할 수 있어 전고상 전지가 가지는 부피 및 에너지 밀도를 증가 시킬 수 있다. ${ }^{9}$ 또한, 전고상 전지에서는 유기 액체 전해 질, 전해질 염, 분리막 및 바인더를 필요로 하지 않아 제 조 공정을 간소화하고 비용을 줄일 수 있는 장점을 가지
고 있다.

그러나 벌크형 전고상 전지는 전극과 고체 전해질인 고 체-고체 계면에서 내부 저항 증가로 인해 전지가 가지는 성능이 저하 이를 향상시키기 위해 가장 중요한 요소는 고체-고체 계면에서 안정성을 확보하는 것이다. 전고상 전지에서 전기화학 반응에 대한 속도에 제한을 줄 수 있 는 전극과 전해질에서 두 가지 유형의 고체-고체 계면이 존재한다. ${ }^{10)}$ 첫 번째는 고체 전해질에서 결정립(graingrain)계면이다. 전고상 전지에서 고체 전해질이 가지는 이온 전도도는 고체 전해질 벌크가 가지는 이온 전도도 및 고체 전해질 결정 입계(grain boundary)에서 이온 전 도도를 나타낸 것으로 열악한 결정립 계면에서 높은 계면 저항(interfacial resistance)은 고체 전해질이 가지는 이 온 전도도를 저하시키는 주된 원인이 된다. ${ }^{11)}$ 두 번째는 전극 복합체에서 고체 전해질과 전극 활물질 또는 도전제 (carbon additives) 사이에 존재하는 고체-고체 계면이 다. 전극과 전해질 계면에서 주된 문제점은 고체 전해질 과 전극 사이의 작은 접촉 영역 및 전극 복합체에서 탄소 첨가제와 전극 활물질 간의 접촉 저하이다. 이런 계면에 서 소재 간 접촉 저하는 높은 전하 전달 저항(charge transfer resistance)을 초래 전고상 전지가 가지는 효율 및 사이클 안정성을 저하시킬 수 있다. ${ }^{11)}$ 또한, 전극 복합 체에서 고체 전해질과 탄소 복합체는 전극 내에서 $\mathrm{Li}$ 이 온과 전자의 확산 경로 역할을 하기 때문에 우수한 전 극-전해질 계면은 전극 복합체 내에 효율적인 전기화학 반응을 위해 빠른 $\mathrm{Li}$ 이온 및 전자 전도도를 확보할 수 있 


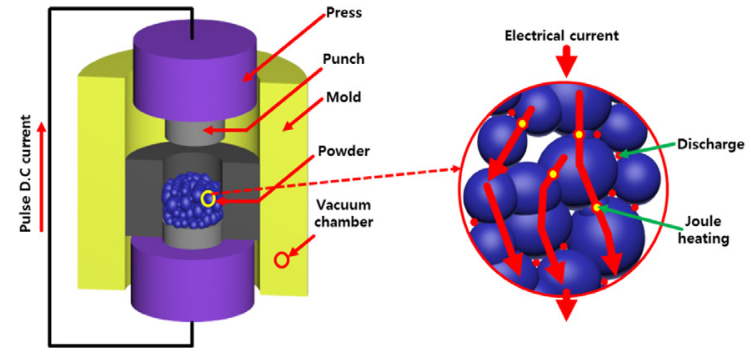

Fig. 2. Spark Plasma Sintering (SPS) 모식도 및 원리

다. 따라서, 전고상 전지가 가지는 계면 저항을 줄이고, 고 에너지 및 전력 밀도를 달성하기 위해서는 우수한 고 체 전해질에서 결정 입계와 전극과 고체 전해질의 고체고체 계면에서 우수한 안정성을 확보하는 것이다.

고체-고체 계면 안정성은 전극과 전해질의 소결 (sintering) 기술에 의해 결정된다. 저온 및 고온 압축 공 정(cold-and hot-press)과 같은 공정 기술이 전고상 전 지의 전극 복합체 및 고체 전해질을 제조하기 위해서 사 용되었지만, 전극 및 전해질에서 고밀도 및 안정화된 고 체-고체 계면을 확보하는데 한계가 있었다. ${ }^{12)}$ 따라서, 최 근 고밀도 및 우수한 고체-고체 계면에서 안전성을 갖는 고체 전해질 및 전극 복합체를 제조하기 위해서 스파크 플라스마 소결(Spark Plasma Sintering (SPS))이 새로 운 소결 기술로 많은 관심을 받고 있다. ${ }^{13-15)}$

SPS 공정은 낮은 대기압에서 펄스된 직류를 사용하여 고온 압축 공정을 통해 분말을 신속하게 소결하는 공정으 로 전형적인 SPS 공정은 입자를 통과하는 펄스 전류에 의해 분말 입자 간 접촉점에서 방전 플라즈마를 형성하고 줄열(Joule heating)을 통해 가열하여 소결을 진행하며, 전류, 압력 및 높은 가열 속도의 조합을 이용 분말 입자 사이의 치밀한 고체-고체 계면을 형성할 수 있다. (Fig. 2) 또한, 분말 입자 사이의 접촉점에서 발생되는 국부적 인 고온은 분말 입자상의 흡착성 기체 및 불순물을 제거 할 수 있다. 이런 SPS 공정에서 펄스된 직류 사용에 따른 고온과 함께 고부하 압력은 일반적인 소결 보다 소결 속 도가 빠른 장점을 가지고 있으며, 이렇게 빠른 소결 속도 는 확산 메커니즘을 촉진하는 입자 성장을 통해 분말의 치밀화를 향상시킬 뿐만 아니라 기존에 소결공정에서 통
상적으로 일어나는 결정입 조대화(grain coarsening)를 방지하여 분말의 고유 특성을 유지하고 고밀도를 가지는 소재를 제작할 수 있다. 또한, SPS에 의한 소결은 상당히 짧은 유지 시간(보통 2-10 $\mathrm{min}$ )으로 전도성 물질에 대한 이론적 밀도에 거의 도달할 수 있다. ${ }^{16)}$ 이런 SPS의 장점 은 전해질 및 전극에서 원하고자 하는 고체-고체 계면에 서 안정성 확보와 소재의 소결 특성을 향상시킬 수 있어 전고상 전지가 가지는 전반적인 성능을 증가시킬 수 있는 매우 유망한 기술 중에 하나이다. 따라서, 본 논문에서는 고체 전해질과 전극 복합체 제조를 기반으로 전고상 전지 제조를 위한 SPS 적용에 대한 연구와, 전고상 전지 제조 를 위한 SPS 적용과 관련된 향후 가능성과 보완해야할 내용에 대해 소개하고자 한다.

\section{2. 본론}

\section{1 고체 전해질을 위한 SPS}

전고상 전지에서 고체 전해질은 중요한 소재 중에 하나 이며, 일반적으로 전고상 전지 적용을 위해서 고체 전해 질이 가지는 특성은 다음과 같은 조건을 충족해야 한 다. ${ }^{17)}$

(1) 상온에서 $10^{-4} \mathrm{~S} \mathrm{~cm}^{-1}$ 보다 높은 이온 전도도

(2) 리튬 금속과 산화/환원 반응에 따른 안정성

(3) 높은 소결 특성

(4) 전극과 고체 전해질 계면에서 낮은 접촉 저항

(5) 높은 소결 온도에 따른 구조적 안정성

(6) 높은 기계적 강도

최근 연구에 따르면 전고상 전지 적용을 위한 Garnet, NASiCON, Perovskite 기반 고체 전해질이 SPS 공정을 통해 제조되어 공정 동안에 고체 전해질이 가지는 결정립 과 결정립계의 제어를 통해 고체 전해질이 가지는 이온 전도도를 향상시킬 수 있었다.

Garnet 기반 고체 전해질은 $\mathrm{Li}_{5} \mathrm{La}_{3} \mathrm{M}_{2} \mathrm{O}_{12}(\mathrm{M}=\mathrm{Nb}, \mathrm{Ta}$, $\mathrm{Bi}$ 화학적 구조를 가지며, 리튬 금속에 대한 화학적 및 열적 안전성과 환경 친화성 등의 우수한 특성으로 많은 
연구가 진행되었다. ${ }^{18)}$ 그러나 Garnet 기반 고체 전해질 은 기존의 고상 합성법을 통해 원하고자 하는 cubic 상을 가지는 $\mathrm{Li}_{7} \mathrm{La}_{3} \mathrm{Zr}_{2} \mathrm{O}_{12}$ (LLZO)을 합성하기 위해서는 높은 소결 온도 $\left(1230{ }^{\circ} \mathrm{C}\right)$ 및 긴 소결 시간 (> 30-40 h)을 필 요로 한다. 이런 cubic 상를 가지는 Garnet 기반 고체 전 해질은 tetragonal 상을 가지는 고체 전해질 $\left(10^{-6} \mathrm{~S} \mathrm{~cm}^{-1}\right)$ 보다 상온에서 높은 $10^{-3} \mathrm{~S} \mathrm{~cm}^{-1}$ 의 벌크 이온 전도도를 가진다. 그러나 높은 온도 및 긴 시간을 필요로 하는 기존 의 합성법은 $\mathrm{LLZO}$ 구조에서 $\mathrm{Li}$ 이 빠져나오거나 증발로 인해 원하지 않은 $\mathrm{La}_{2} \mathrm{Zr}_{2} \mathrm{O}_{7}$ 의 불순물 상을 형성 고체 전 해질이 가지는 이온 전도도를 저하시킨다. 또한, 기존의 방법으로 소결된 LLZO 고체 전해질은 일반적으로 낮은 밀도에 따른 계면 저항의 증가로 고체 전해질이 가지는 이온 전도도가 낮아진다. 이런 측면에서 SPS 공정은 낮 은 소결 온도 및 짧은 소결 시간을 제공하여 바람직한 구 조 형성을 위해 공정 조건을 쉽게 제어하고, 이론 밀도에 근접한 밀도를 가지는 고체 전해질을 합성할 수 있기 때 문에 기존의 합성 공정 보다 고체 전해질을 합성하는데
적합한 공정으로 많은 관심을 받고 있다.

그에 따라, Garnet 기반 고체 전해질을 합성하는데 $\mathrm{SPS}$ 공정을 이용한 연구들이 현재 많이 진행 중에 있다. 2014년도에 Zhang 그룹에서는 Al이 치환된 cubic 상을 가지는 $\mathrm{LLZO}$ 를 $\mathrm{SPS}$ 를 통해 $1150{ }^{\circ} \mathrm{C}$ 소결 온도에서 10 분 이내로 제작하였다. 이렇게 제작된 고체 전해질은 $99.8 \%$ 높은 상대밀도와 상온에서 $5.7 \times 10^{-4} \mathrm{~S} \mathrm{~cm}^{-1}$ 의 이온 전도도를 나타냈다. ${ }^{19)}$ 이 연구는 기존 연구에서 cubic 상을 가지는 LLZO를 합성하기 위해서 필요로 하 는 온도가 기존의 고상 반응 합성 $\left(1250{ }^{\circ} \mathrm{C}\right)$ 보다 상대적 으로 낮은 것을 보여주었으며, 위 연구에서 더 중요한 사 항은 짧은 소결 시간으로 인해 $\mathrm{Li}$ 의 증발을 막아 합성 시 추가적인 Li resource의 추가가 필요하지 않는 다는 것 을 보여주었다. 다른 연구로 분무 스프레이 열분해 법 (nebulized spray pyrolysis)을 가지고 합성된 0.3 5 $\mu \mathrm{m}$ 의 크기를 가지는 $\mathrm{Li}_{7-3 x} \mathrm{La}_{3} \mathrm{Zr}_{2} \mathrm{Al}_{\mathrm{z}} \mathrm{O}_{12}(\mathrm{x}=0.15,0.17$, $0.20)$ 분말을 합성 후 $950{ }^{\circ} \mathrm{C}$ 에서 10 분 동안 $\mathrm{SPS}$ 공정 을 통해서 고체 전해질을 제작했다. ${ }^{20)} \mathrm{XRD}$ 를 이용 구조 (a)

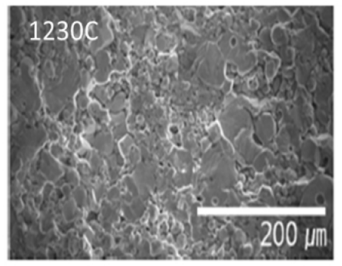

(b)
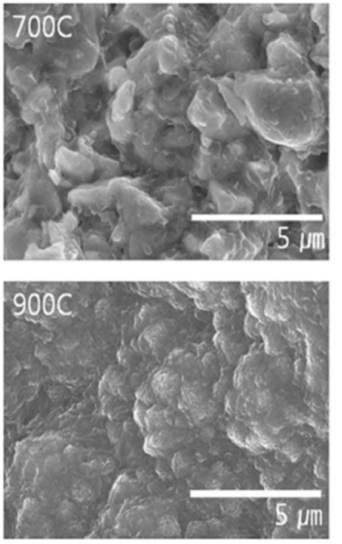
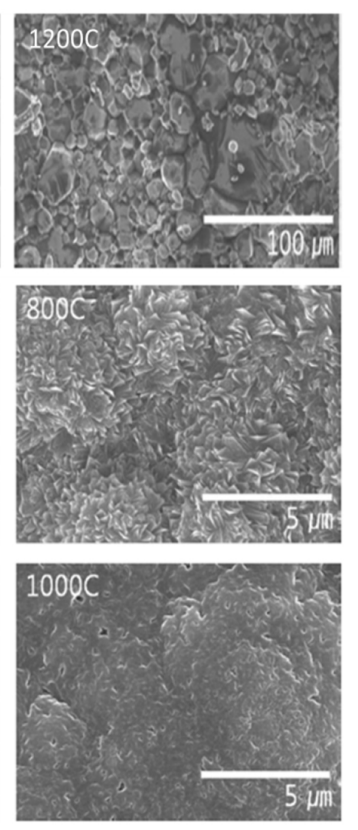

(c)
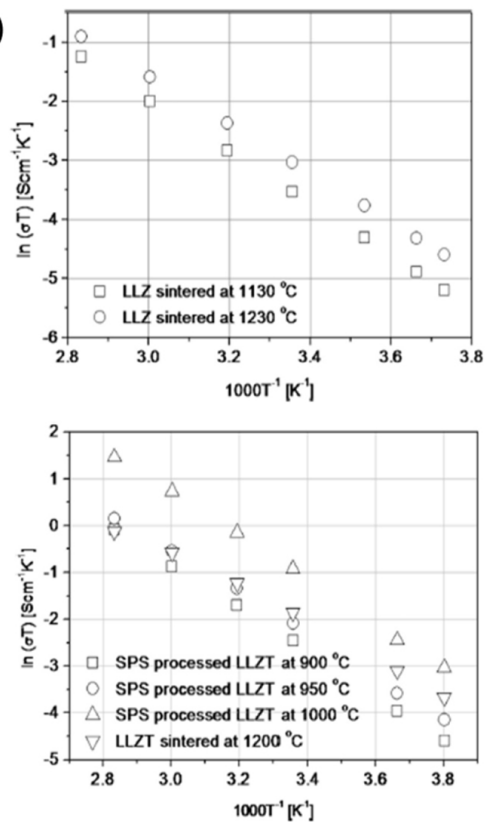

Fig. 3. $\mathrm{Li}_{7-x} \mathrm{La}_{3} Z \mathrm{r}_{1.5} \mathrm{Ta}_{0.5} \mathrm{O}_{12-\mathrm{d}}$ 의 미세구조 및 이온 전도도 특성. (a) 전형적인 공정을 통해 $1230{ }^{\circ} \mathrm{C}$ 와 $1200{ }^{\circ} \mathrm{C}$ 에서 소결된 $\mathrm{Li}_{7-x} \mathrm{La}_{3} \mathrm{Zr}_{1.5} \mathrm{Ta}_{0.5} \mathrm{O}_{12-\mathrm{d}}$ 의 SEM. (b) SPS 공정을 통해 700-1000 ${ }^{\circ} \mathrm{C}$ 까지 소결된 $\mathrm{Li}_{7-x} \mathrm{La}_{3} Z \mathrm{r}_{1.5} \mathrm{Ta}_{0.5} \mathrm{O}_{12-\mathrm{d}}$ 의 SEM. (c) 전형적인 소결과 SPS 공정을 통해 소결된 $\mathrm{Li}_{7-x} \mathrm{La}_{3} \mathrm{Zr}_{1.5} \mathrm{Ta}_{0.5} \mathrm{O}_{12-\mathrm{d}}$ 의 이온 전도도. ${ }^{22)}$ 
분석 결과, $\mathrm{Al}$ 이 도핑 성분에 관계없이 소결된 모든 시료 에서 $\mathrm{La}_{2} \mathrm{ZrO}_{7}$ 과 tetragonal 상 $\mathrm{LLZO}$ 을 함유하고 있는 것을 확인했다. 이 결과는 Zhang 그룹의 연구에서 비슷 한 온도 $\left(900-1000{ }^{\circ} \mathrm{C}\right)$ 에서 소결된 $\mathrm{Al}$ 이 치환된 $\mathrm{LLZO}$ 에 서 두개의 불순물 상이 발견되어 비슷한 결과를 보였으 며, 소결 온도에 따라 $\mathrm{La}_{2} \mathrm{ZrO}_{7}$ 과 tetragonal 상을 가지 는 LLZO가 생성되는 높은 민감함을 나타냈다. 그러나 이결과는 두개의 불순물 상 형성에도 불구하고 상온에서 높은 이온 전도도인 $3 \times 10^{-4} \mathrm{~S} \mathrm{~cm}^{-1}$ 및 $0.38 \mathrm{eV}$ 의 활성 화 에너지를 나타냈으며, 고체 전해질이 가지는 이온 전 도도는 cubic 상을 가지는 LLZO의 이온 전도도와 비슷 한 값은 나타냈다. 이 결과는 tetragonal 상을 가지는 $\mathrm{LLZO}$ 는 SPS 공정 동안 미세 변형의 도입에 의해 야기되 었을 것이라 예상했으며, tetragonal 상을 가지는 LLZO 와 비교하여 $\mathrm{Li}$ 이온 전도도에 영향을 주지 않는다고 설 명했다. 또한, Garnet 기반 고체 전해질이 Li과 반응성 확인을 위해서 $\mathrm{Li}\left|\mathrm{Li}_{3 x} \mathrm{La}_{3} \mathrm{Zr}_{2} \mathrm{Al}_{2} \mathrm{O}_{12}\right| \mathrm{Li}$ 셀을 구성 $100 \mathrm{~h}$ 동안 사이클 특성을 평가한 결과 성능 저하 없이 우수한 사이클 특성을 보였으며, 사이클 후 고체 전해질과 Li과 의 계면 저항 증가가 없는 것을 확인했다. ${ }^{21)}$ 위에 두 연구 결과를 바탕으로 SPS 공정은 높은 밀도 및 이온 전도도 를 가지는 LLZO 고체 전해질을 빠른 소결을 통해서 제 작할 수 있다는 것을 확인시켜주었으며, SPS의 소결 온 도가 기존의 소결 방법보다 낮더라도 SPS 공정 시 온도 는 분말 표면에서 발생하는 것으로 추측되는 불필요한 불 순물 상 형성을 최소화하기 위해서 SPS 공정 최적화를 위한 연구가 더 필요하다고 제안했다.

최근에는 고체 전해질이 가지는 이온 전도도를 증가시 키기 위해서 Garnet 기반 고체 전해질에 양이온 도핑을 통해 구조 안정성 및 이온 전도도를 향상시킬 수 있었으 며, SPS 공정을 통해 고체 전해질이 가지는 이온 전도도 를 더욱 높일 수 있었다. Baek 그룹은 고체 전해질이 가 지는 구조적 안정성을 향상시키기 위해서 LLZO에 Ta가 도핑된 $\mathrm{Li}_{7-\mathrm{x}} \mathrm{La}_{3} \mathrm{Zr}_{1.5} \mathrm{Ta}_{0.5} \mathrm{O}_{12-\mathrm{d}}$ 고체 전해질을 합성했으 며, ${ }^{22)} \mathrm{SPS}$ 공법으로 제작된 $\mathrm{Li}_{7-\mathrm{x}} \mathrm{La}_{3} \mathrm{Zr}_{1.5} \mathrm{Ta}_{0.5} \mathrm{O}_{12-\mathrm{d}}$ 의 미 세 구조와 이온 전도도에 대한 특성을 기존의 소결 공법 과 비교 분석하였다. (Fig. 3) 기존의 전형적인 공정으로
소결한 $\mathrm{Li}_{7-\mathrm{x}} \mathrm{La}_{3} \mathrm{Zr}_{1,5} \mathrm{Ta}_{0.5} \mathrm{O}_{12-\mathrm{d}}$ 는 기공 형성에 따른 높은 결정 입계 저항을 유도하는 전체 구조에 걸쳐 불균일한 밀도를 보였으며(Fig. 3a), 이와 반대로 SPS 공정을 통 해 소결된 $\mathrm{Li}_{7-\mathrm{x}} \mathrm{La}_{3} \mathrm{Zr}_{1.5} \mathrm{Ta}_{0.5} \mathrm{O}_{12-\mathrm{d}}$ 는 고밀도 구조를 가져 상온에서 높은 이온 전도도인 $1.35 \times 10^{-3} \mathrm{~S} \mathrm{~cm}^{-1}$ 을 나 타냈다. (Fig. 3c) 이 결과는 미세구조 결과에서 보는 것 과 같이 기존에 전형적인 소결을 통해 제작된 고체 전해 질은 기공이 형성된 반면에, SPS 공정에 의해 소결된 고 체 전해질은 기공 없이 고체 전해질이 치밀하게 형성된 것에 기인한다고 판단했다. (Fig. $3 \mathrm{~b}$ )

LLZO 및 $\mathrm{Li}_{7} \mathrm{La}_{3} \mathrm{Ta}_{2} \mathrm{O}_{12}$ 외에도, $\mathrm{Li}_{5} \mathrm{La}_{3} \mathrm{Nb}_{2} \mathrm{O}_{12}$ 및 $\mathrm{Li}_{5} \mathrm{La}_{3} \mathrm{Bi}_{2} \mathrm{O}_{12}$ 와 같은 다른 종류의 Garnet 기반 고체 전해 질이 SPS에 의해 제조되고, 우수한 이온 전도도를 나타 내었다. Mohamad 그룹은 SPS 공정을 통해 $\mathrm{Li}_{5} \mathrm{La}_{3} \mathrm{Nb}_{2} \mathrm{O}_{12}$ 고체 전해질을 제조하였다. ${ }^{23)}$ 전형적인 공정으로 소결된 고체 전해질은 입계 사이즈가 $1-2 \mu \mathrm{m}$ 의 거친 구조를 갖 는 반면, SPS 공정에 의해 소결된 고체 전해질은 50$100 \mathrm{~nm}$ 의 크기를 갖는 나노 크기의 입계를 갖는 것을 확 인했다. 미세구조 분석 결과 SPS 공정을 통해 소결된 고 체 전해질에서는 기공이 감소하고 입계 간 결함이 개선된 것을 확인했다. 그 결과, $850{ }^{\circ} \mathrm{C}$ 에서 $\mathrm{SPS}$ 에 의해 소결 된 $\mathrm{Li}_{5} \mathrm{La}_{3} \mathrm{Nb}_{2} \mathrm{O}_{12}$ 는 상온에서 $3.7 \times 10^{-5} \mathrm{~S} \mathrm{~cm}^{-1}$ 의 이온 전 도도를 나타냈으며, 전형적인 공정으로 소결된 고체 전해 질이 가지는 이온 전도도 보다 높은 것을 확인했다. ${ }^{24)}$ 또 다른 결과로, $\mathrm{SPS}$ 에 의해 제조된 $\mathrm{Li}_{5} \mathrm{La}_{3} \mathrm{Bi}_{2} \mathrm{O}_{12}$ 고체 전해 질은 Garnet 기반 구조 및 97\% 상대 밀도 나타냈으며, $\mathrm{Li}_{5} \mathrm{La}_{3} \mathrm{Bi}_{2} \mathrm{O}_{12}$ 고체 전해질이 가지는 이온 전도도는 상온 에서 $5.1 \times 10^{-5} \mathrm{~S} \mathrm{~cm}^{-1}$ 의 이온 전도도를 나타냈다. ${ }^{25)}$

또다른 고체 전해질로 NASICON 기반 $\mathrm{LiM}_{2}\left(\mathrm{PO}_{4}\right)_{3}$ $(\mathrm{M}=\mathrm{Ti}, \mathrm{Ge}, \mathrm{Zr}, \mathrm{Hf})$ 은 $\mathrm{Li}$ 이온에 유리한 전도 터널을 갖 는 또 다른 고체 전해질 그룹이며, 대기에서 높은 화학적 안정성에 때문에 많은 연구가 되어왔다. NASICON 기반 고체 전해질이 가지는 이온 전도도는 원소 치환에 의해 향상되었지만, Garnet 기반 고체 전해질과 유사하게 높 은 결정립계 저항과 높은 밀도를 가지는 고체 전해질을 얻는데 어려움이 있어 이런 문제들은 NASICON 기반 고 체 전해질의 상용화를 제한했다. 최근 SPS는 높은 계면 
저항에 대한 문제를 해결하고, 고체 전해질의 밀도를 향 상 시켜 NASICON 기반 고체 전해질이 가지는 이온 전 도도 향상을 위해 많이 적용되어왔다.

Chang 그룹은 $\mathrm{LiTi}_{2}\left(\mathrm{PO}_{4}\right)_{3}(\mathrm{LTP}), \mathrm{Li}_{1.3} \mathrm{iAl}_{0.3} \mathrm{Ti}_{1,7}\left(\mathrm{PO}_{4}\right)_{3}$ (LATP), and $\mathrm{Li}_{1.3} \mathrm{Al}_{0.3} \mathrm{Ti}_{1.7}\left(\mathrm{PO}_{4}\right)_{2.9}\left(\mathrm{VO}_{4}\right)_{0.1}$ (LATPV) 고 체 전해질을 $\mathrm{SPS}$ 와 전형적인 소결 공정으로 제조 후 소 결 방법과 조건에 따라 LTP, LATP 및 LATPV의 미세 구 조가 이온 전도도에 미치는 영향을 평가했다. ${ }^{26)}$ (Fig. 4) 전형적인 공법으로 소결된 LTP는 $76 \%$ 의 상대 밀도에 따 른 미세 기공을 가지는 것을 확인했으며, 그와 달리 1100 ${ }^{\circ} \mathrm{C}$ 에서 $\mathrm{SPS}$ 에 의해 소결된 LTP는 미세 기공 없는 $94 \%$ 의 상대 밀도를 가지는 것을 확인했다. (Fig. $4 \mathrm{~g}$ ) 그 결 과, SPS 공정에 의해 제작된 LAP가 가지는 이온 전도도 는 기존의 소결 공정으로 제작된 고체 전해질 $\left(2.7 \times 10^{-5}\right.$ $\mathrm{S} \mathrm{cm}^{-1}$ ) 보다 높은 상온에서 $1.4 \times 10^{-6}$ 을 나타냈다. (Fig. 4h) $\mathrm{Al}$ 및 $\mathrm{V}$ 이온이 치환된 NASICON 고체 전해 질은 전형적인 소결 공정에서 보다 SPS 공정에서 더욱 밀도가 높은 미세 구조 및 증가된 상대 밀도를 나타냈으
며, SPS 소결 온도를 1000 에서 $1100{ }^{\circ} \mathrm{C}$ 로 변경하여 고 밀도의 고체 전해질을 제작할 수 있었다. (Fig. $4 \mathrm{~g}$ ) 또한, 전형적인 공정으로 소결된 LATPV를 제외하고 제작된 고체 전해질에서는 입계 성장이 관찰되지 않아 그 결과 $\mathrm{Al}$ 과 $\mathrm{V}$ 이 도핑에서 SPS 공정에 의해 제작된 LATPV는 상온에서 $2.6 \times 10^{-4} \mathrm{~S} \mathrm{~cm}^{-1}$ 의 가장 높은 이온 전도도를 나타냈고, $0.29 \mathrm{eV}$ 의 낮은 활성화 에너지를 보였다. (Fig. 4h) 이 연구는 SPS 공정이 고체 전해질이 가지는 미세 구조의 치밀화를 통해 이론 밀도(95-97\%) 까지 향 상 이온 전도도를 증가시킬 수 있음을 보여주었다.

비슷한 연구로 Wen 그룹에서는 이론 밀도와 거의 비 슷한 고밀도를 가지는 $\mathrm{Li}_{1.4} \mathrm{Al}_{0.4} \mathrm{Ti}_{1.6}\left(\mathrm{PO}_{4}\right)_{3}$ 를 $\mathrm{SPS}$ 공정에 통해서 제작했다. ${ }^{27)} \mathrm{SPS}$ 의 소결 온도 $\left(650{ }^{\circ} \mathrm{C}\right)$ 는 전형적 인 소결(CS (conventional sintering))온도 $850{ }^{\circ} \mathrm{C}$ 보다 훨씬 낮았지만 SPS에 의해 제작된 고체 전해질의 이온 전도도는 입자 크기가 나노 스케일로 감소하여 밀도를 증 가시킬 수 있어 향상될 수 있다는 것을 보고했다. Duluard 그룹은 고순도의 $\mathrm{Li}_{1,3} \mathrm{Al}_{0.3} \mathrm{Ti}_{1.7}\left(\mathrm{PO}_{4}\right)_{3}$ 를 $\mathrm{Sol}-$

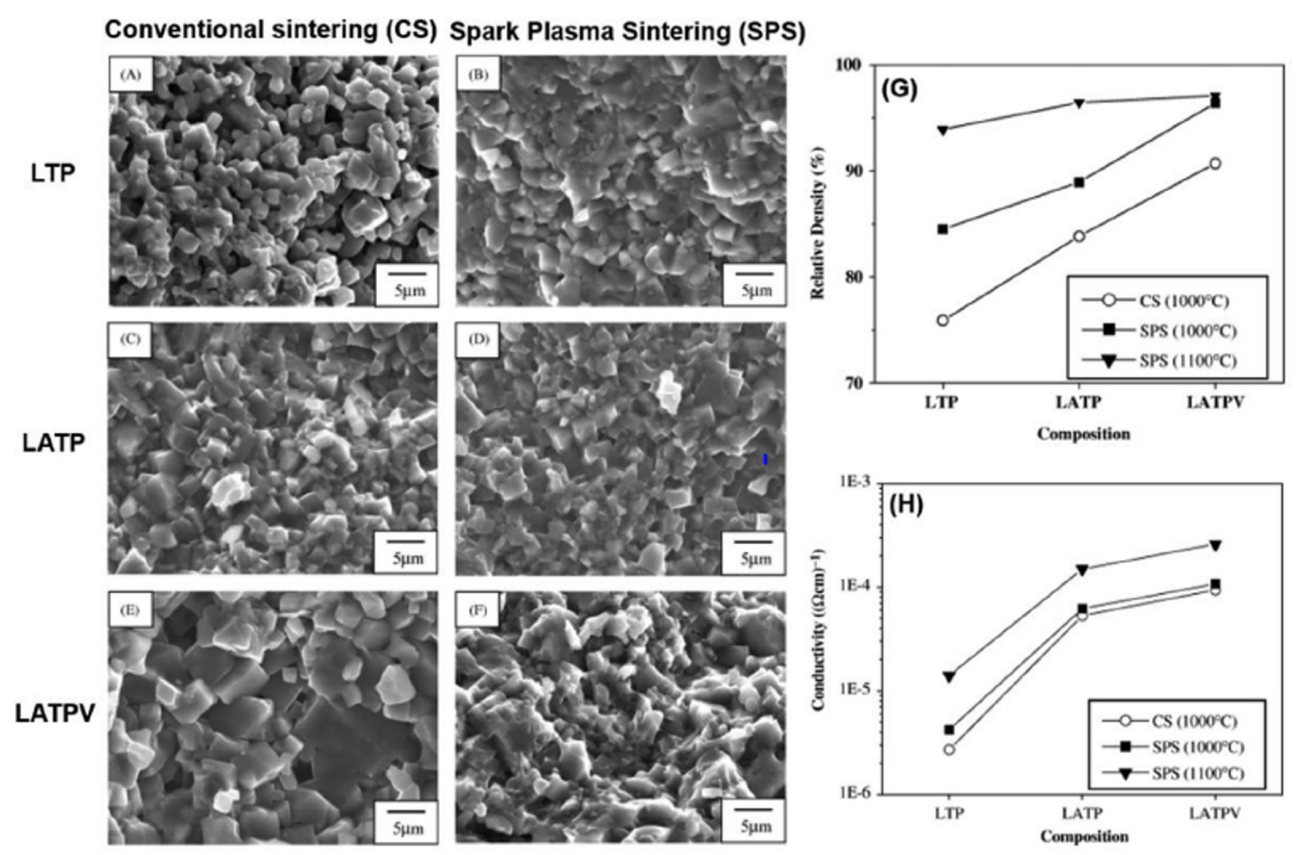

Fig. 4. 전형적인 소결 (conventional sintering (CS))과 SPS로 소결된 고체 전해질의 SEM, 상대 밀도, 이온 전도도 결과. (a) LiTi $2\left(P O_{4}\right)_{3}\left(\mathrm{LTP}_{2}\right)$, CS, (b) LTP, SPS, (c) Li $\mathrm{i}_{1.3} \mathrm{Al}_{0.3} \mathrm{Ti}_{1.7}\left(\mathrm{PO}_{4}\right)_{3}$ (LATP), CS, (d) LATP, SPS, (e) Li $\mathrm{i}_{1.3} \mathrm{Al}_{0.3} \mathrm{Ti}_{1.7}\left(\mathrm{PO}_{4}\right)_{2.9}\left(\mathrm{VO}_{4}\right)_{0.1}(\mathrm{LATPV}), \mathrm{CS}$, (f) LATPV, SPS, (g) 고 체 전해질의상대 밀도, (h) 고체 전해질의 이온 전도도. ${ }^{26)}$ 
gel 공정을 통해 합성 후 SPS 소결을 통해서 고체 전해질 을 제작했다. SPS 공정으로 $850{ }^{\circ} \mathrm{C}$ 소결된 고체 전해질 은 $97 \%$ 의 상대 밀도와 상온에서 $1.6 \times 10^{-4} \mathrm{~S} \mathrm{~cm}^{-1}$ 의 이 온 전도도를 나타냈다. 이와 달리 CS로 제작된 고체 전해 질의 상대 밀도와 이온 전도도를 높이기 위해서는 1100 ${ }^{\circ} \mathrm{C}$ 에서 $1 \mathrm{~h}$ 소결 온도와 시간이 필요했다. 높은 온도에서 소결은 결정립 경계에서 비 리튬 이온 전도성 2차상과 고 체 전해질에서 생성되는 미세 균열을 형성할 수 있기 때 문에 SPS에 의해 낮은 소결 온도는 이런 문제를 해결할 수 있는 장점이 있다고 보고했다. 또한, LATP 고체 전해 질 뿐만 아니라, 다른 NASICON 기반 고체 전해질이 $\mathrm{SPS}$ 공정에 의해 제작되었다. 결정입이 제어된 $\mathrm{Li}_{1.5} \mathrm{Al}_{0.5} \mathrm{Ge}_{1.5}\left(\mathrm{PO}_{4}\right)_{3}$ (LAGP) 고체 전해질을 전구체 결정 화에 의해 먼저 제조 후 SPS 공정을 통해서 고체 전해질 을 제작했다. ${ }^{28)}$ 그 결과 $650{ }^{\circ} \mathrm{C}$ 에서 $2 \mathrm{~min}$ 간 $\mathrm{SPS}$ 공정으 로 소결된 고체 전해질은 $87 \%$ 상대 밀도를 가지며, 상온 에서 $1.3 \times 10^{-4} \mathrm{~S} \mathrm{~cm}^{-1}$ 의 이온 전도도 및 $0.38 \mathrm{eV}$ 활성 화 에너지를 나타냈다. 이렇게 SPS 공정에 의한 낮은 온 도에서 소결은 LAGP 고체 전해질을 전고상 전지 전극 복 합체에도 사용할 수 있다는 장점을 제공했다.

Perovskite 형 고체 전해질로 알려진 $\mathrm{Li}_{3 \mathrm{x}} \mathrm{La}_{(2 / 3-\mathrm{x})} \mathrm{TiO}_{3}$ (LLTO)는 상온에서 $10^{-3} \mathrm{~S} \mathrm{~cm}^{-1}$ 의 높은 벌크 이온 전도 도 나타내기 때문에 전고상 전지에서 고체 전해질로 사용 하기 위해서 많은 관심을 받고 있다. 그러나 전형적인 소 결을 통해 고순도 LLTO 상과 고밀도 고체 전해질을 얻 기 위해서는 긴 소결 시간과 높은 소결 온도 $\left(1300{ }^{\circ} \mathrm{C}\right)$ 를 필요로 한다. Mei 그룹은 $1050{ }^{\circ} \mathrm{C}$ 에서 $3 \mathrm{~min}$ 동안 SPS 공정을 통해 상대 밀도 $98.5 \%$ 를 가지는 LLTO 고체 전해 질을 제작했으며, SPS 소결 온도가 증가함에 따라 상대 밀도 및 이온 전도도가 향상되는 것을 확인했다. ${ }^{29}$ 그러 나 SPS에 의해 제작된 고체 전해질은 높은 벌크 이온 전 도도는 $10^{-3} \mathrm{~S} \mathrm{~cm}^{-1}$ 을 나타낸 반면에 결정 입계(grain boundary)를 포함한 전체적인 이온 전도도는 $5.8 \times$ $10^{-6} \mathrm{~S} \mathrm{~cm}^{-1}$ 을 나타냈다. 이 결과는 전체적인 이온 전도 도에서 결정 입계(grain boundary)에서 이온 전도도가 낮아 고체 전해질이 가지는 이온 전도도가 감소했으며, $\mathrm{Li}$ 손실과 작은 입계에서 $\mathrm{La}_{2} \mathrm{Ti}_{2} \mathrm{O}_{5}$ 의 불순물 상 형성으로
인해 고체 전해질이 가지는 이온 전도도를 방해하기 때문 에 이온 전도도가 감소한 것이라 보고했다. 또다른 연구 로 LLTO 고체 전해질이 $1100{ }^{\circ} \mathrm{C}$ 에서 $5 \mathrm{~min}$ 동안 $\mathrm{SPS}$ 공정을 통해 제작되었다. ${ }^{30)}$ 이렇게 제작된 고체 전해질은 결정 입계와 벌크 이온 전도도 기여에 대해서 자세한 언 급은 없었지만, 전형적으로 LLTO가 가지는 이온 전도도 $\left(10^{-3} \mathrm{~S} \mathrm{~cm}^{-1}\right)$ 를 상온에서 나타냈으며, $30.1 \mathrm{kj} \mathrm{mol}^{-1}$ 의 활성화 에너지를 가진다고 보고했다.

\section{2 전극 복합체를 위한 SPS}

고체 전해질 제조 외에도, SPS는 조밀하고 미세한 미 세 구조를 갖는 물질을 제조하는데 있어 장점이 있기 때 문에 전고상 전지 전극 복합체를 제조하는데 사용되어왔 다. 전고상 전지의 전극 복합체는 Fig. $1 \mathrm{~b}$ 에서 보는 것과 같이 전극 활물질, 고체 전해질 및 탄소 첨가물로 구성된 다. 따라서 전극 복합체에서 $\mathrm{Li}$ 이온 및 전자의 빠른 이동 을 위해서 전극 복합체 내에 고체 전해질 및 탄소 첨가물 의 접촉이 중요한 역할을 한다. 이것은 전극 활물질, 고 체 전해질 및 탄소 첨가제 간의 우수한 표면 접촉은 $\mathrm{Li}$ 이 온 및 전자의 이동도를 향상 시키고, 전극 및 전해질의 응 집력을 향상 시켜 전고상 전지가 가지는 계면 저항을 감 소시키는데 필수적이다. 또한, 높은 충/방전율을 얻기 위 해서 전극 활물질에서 $\mathrm{Li}$ 이온 및 전자의 확산 길이를 줄 이기 위해서 전고상 전지에서 나노 구조 물질을 사용할 필요가 있다. 따라서, 전고상 전지 전극 복합체를 설계할 때 중요한 과제는 전극 활물질, 고체 전해질 및 탄소 첨가 물 간의 친밀한 접촉을 실현하는 방법이며 구조 내 미세 한 입자 크기 및 분포를 유지하는 것이다.

Bouchet 그룹은 SPS 공법을 사용하여 $\mathrm{Li}_{3} \mathrm{~V}_{2}\left(\mathrm{PO}_{4}\right)_{3} /$ $\mathrm{Li}_{3} \mathrm{Al}_{0.5} \mathrm{Ge}_{0.5}\left(\mathrm{PO}_{4}\right)_{3} / \mathrm{Li}_{3} \mathrm{~V}_{2} \quad\left(\mathrm{PO}_{4}\right)_{3} \quad(\mathrm{LVP} / \mathrm{LAGP} / \mathrm{LVP})$ 와 $\mathrm{LiFePO} / 4 \mathrm{Li}_{1.5} \mathrm{Al}_{0.5} \mathrm{Ge}_{1.5}\left(\mathrm{PO}_{4}\right)_{3} / \mathrm{Li}_{3} \mathrm{~V}_{2}\left(\mathrm{PO}_{4}\right)_{3}(\mathrm{LFP} / \mathrm{LAG} /$ $\mathrm{LVP})$ 의 셀 구성을 갖는 전고상 전지를 제조하는 두가지 성공적인 사례를 보고했다. ${ }^{31-32)}$

$\mathrm{LVP} / \mathrm{LAGP} / \mathrm{LVP}$ 구성에서 $\mathrm{Li}_{3} \mathrm{~V}_{2}\left(\mathrm{PO}_{4}\right)_{3}$ 전극 물질은 작동 전압이 3 에서 $4.2 \mathrm{~V}$ 사이에서는 $120 \mathrm{mAh} \mathrm{g}^{-1}$ 와 1.8 에서 $3 \mathrm{~V}$ 사이에는 $80 \mathrm{mAh} \mathrm{g}^{-1}$ 을 보여주고, $\mathrm{LVP}$ 의 작동 전압은 LAGP의 전기 화학적 안정 전위가 유사함을 가지 
(a)
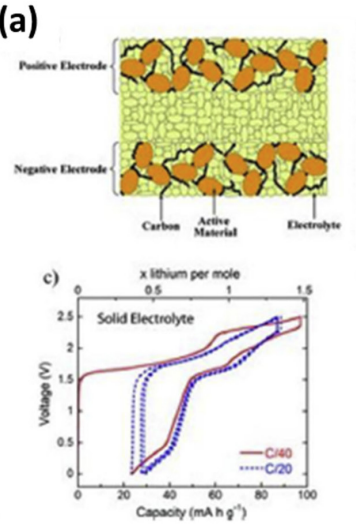
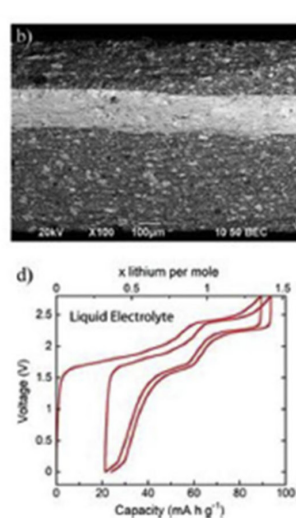

(b)

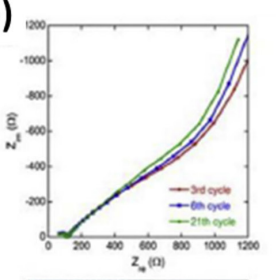

1

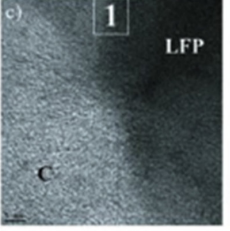

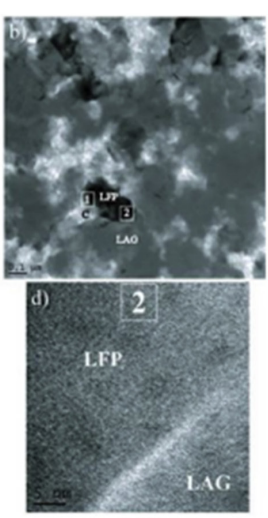

Fig. 5. (a) 전고상 전지 모식도 및 cross-section SEM, (a)-c) LVP/LAGP/LVP 셀의 전기화학 특성, (a)-d) LVP/LVP 셀의 액체 전해질 상에 서 전기화학 특성, (b)-a) 전기화학 반응 사이클 후 LFP/LAGP/C 전극 복합체의 EIS 특성, (b)-b) LFP/LAGP/C 전극 복합체의 TEM 결과, (b)-c) and -d) (b)-b)에서 Zone 1과 2에서 HR-TEM 결과. ${ }^{31-32)}$

기 때문에 전고상 전지 두 전극으로 선택되었다. (Fig. $5 \mathrm{a}-\mathrm{a}$ and $5 \mathrm{a}-\mathrm{b}$ ) 두 전극에 대한 최적화된 전극 활물질/ 고체 전해질/탄소 첨가물의 중량비는 $25 / 60 / 15$ 였으며, 전기화학 테스트는 상온에서 액체 전해질을 사용하는 $\mathrm{LVP} / \mathrm{LVP}$ 셀에서 가지는 용량과 비슷한 $80 \mathrm{mAh} \mathrm{g}^{-1}$ 의 가역용량을 $80{ }^{\circ} \mathrm{C}$ 에서 나타냈다. (Fig. $5 \mathrm{a}-\mathrm{c}$ and $5 \mathrm{a}-\mathrm{d}$ ) 이번 연구에서 $80{ }^{\circ} \mathrm{C}$ 의 작동 온도는 셀에서 LAGP가 가
지는 이온 전도도가 전고상 전기 작동을 위해 요구되는 $10^{-4} \mathrm{~S} \mathrm{~cm}^{-1}$ 을 필요로 했기 때문에 설정했으며, SPS 공 정에 의해 전고상 전지를 원스텝으로 제조할 수 있는 가 능성과 전자 및 이온 이동성에 대한 한계에도 전고상 전 지에서 사이클 운전이 가능하다는 것을 보여줬다.

LVP/LAGP/LVP 셀 경우에는 LFP/LVP 중량비를 두 전극의 최대 가역용량을 얻기 위해서 0.7 로 설정하였다. (a)
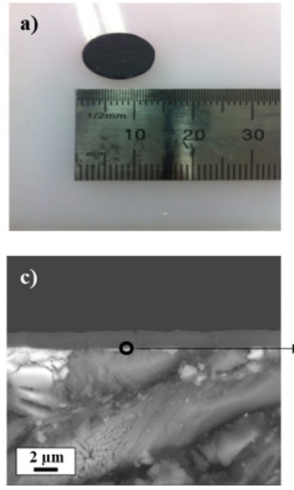

(c)

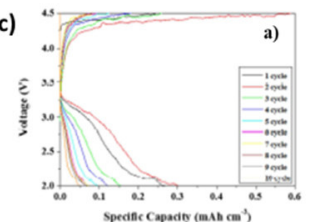

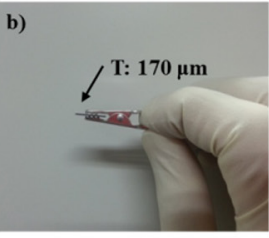

d)
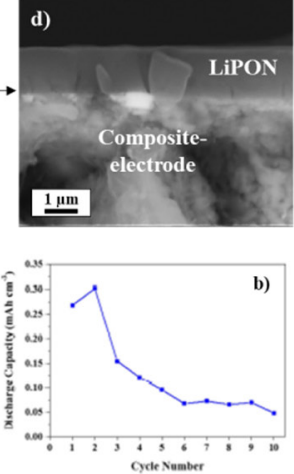

(b)
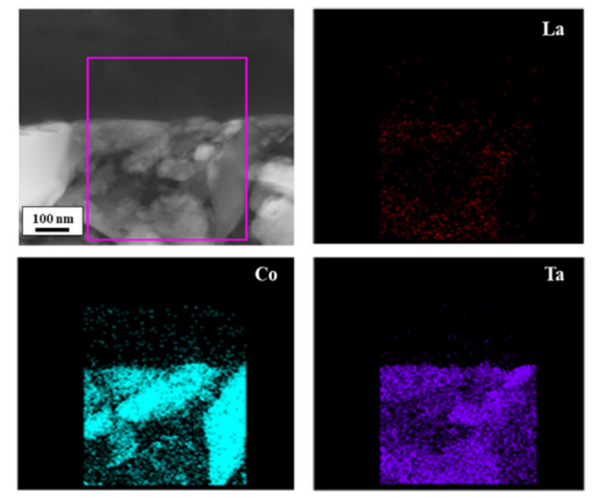

(d)
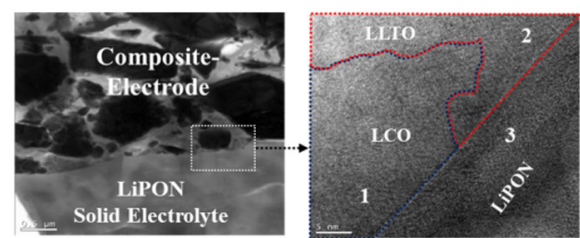

Fig. 6. (a)-a) and -b) LCO/LLTO/MWCNTs 전극 복합체 이미지, (a)-c) and -d) LIPON 박막형 고체 전해질이 증착 전극 복합체의 SEM 결 과, (b) 충방전 사이클 후 전극과 고체 전해질 계면에서 EDS 결과, (c) LCO/LLTO/MWCNTS 전극 복합체의 충방전 및 사이클 특성, (d) LCO/LLTO/MWCNTS 전극 복합체와 LPON 박막 고체 전해질 계면에서 TEM 결과.33) 
특 집 ㄸㅃ 이석희

전기화학 평가 결과 $\mathrm{LVP} / \mathrm{LAGP} / \mathrm{LVP}$ 셀은 $120{ }^{\circ} \mathrm{C}$ 인 $\mathrm{C} / 20$ 에서 $80 \mathrm{mAh} \mathrm{g}^{-1}$ 의 용량을 가지며, 30 사이클 후에 초기 용량의 $80 \%$ 가 유지되는 우수한 사이클 특성을 보였 다. 또한, 사이클 특성 후 EIS 분석 결과 셀 저항에 큰 변 화가 없는 것을 확인했다. (Fig. $5 \mathrm{~b}-\mathrm{a}$ ) 이결과는 사이클 후에 TEM 분석을 사용하여 고체 전해질과 전극 활물질 간의 인터페이스를 분석한 결과 전극에서 균열이 발생되 지 않고, $\mathrm{LFP}$, 탄소 첨가제 및 고체 전해질 간의 우수한 접촉을 유지하고 있어 셀이 가지는 성능을 유지할 수 있 는 것이라 보고했다. (Fig. $5 \mathrm{~b}-\mathrm{c}$ and $5 \mathrm{~b}-\mathrm{d}$ ) 또한, 이번 연구에서는 전고상 셀 내에 $15 \%$ 의 잔류 기공은 전기 화 학 반응 과정에서 LFP와 LVP의 국부 응력을 완화 가능
하기 때문에 전극에 결함을 없게 하기 위해서는 필수적이 라고 제안했다. 잘 알려진 바와 같이, 리튬화 및 탈리튬 (lithiation and delithiation) 과정 동안에 전극 물질의 부피 변화는 전해질로부터 전극 활물질의 박리를 야기 $\mathrm{Li}$ 이온의 확산 경로를 방해할 수 있어, 이번 연구는 의도적 으로 전극 복합체에 잔류 기공을 존재 시킴으로 전극 결 함 문제에 대한 해결책을 제시했다.

최근 연구에서 $\mathrm{SPS}$ 를 사용하여 전고상 $\mathrm{LiCoO}_{2}(\mathrm{LCO})$ 전극 복합체를 제조하고, $\mathrm{Li}$ 금속을 상대 전극으로 사용 하여 전고상 전지의 성능을 평가했다.

$\mathrm{Lee}$ 와 동료 연구자들은 $\mathrm{LCO}, \mathrm{Li}_{5} \mathrm{La}_{3} \mathrm{Ta}_{2} \mathrm{O}_{12}$ (LLTO)와 탄소 나노튜브(MWCNTs) 사이의 중량비를 SPS 공정을

\section{(a)}
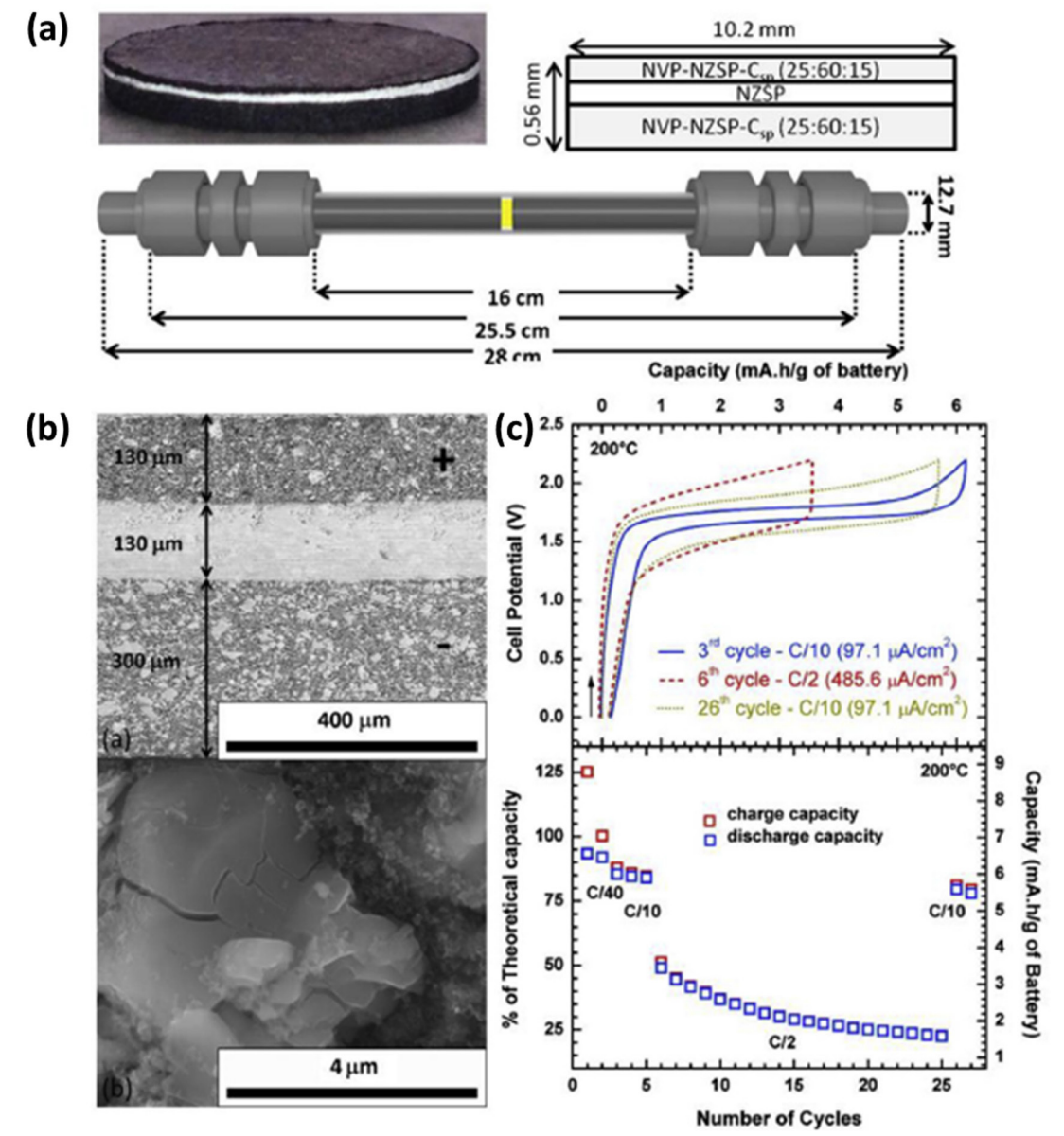

Fig. 7. (a) NVP/NZSP/NVP 셀 구조, (b) 30 사이클 후 전고상 NVP 입계가 가지는 미세구조 결과, (c) NVP/NZSP/NVP 셀이 가지는 충/방전 특성 및 사이클 안전성 결과 ${ }^{35}$ 
통해 최적화하여 전자 및 $\mathrm{Li}$ 이온 전도를 가지는 전고상 전지를 구현했다. ${ }^{33)}$ 최적의 조성은 중량비로 $32 \mathrm{LCO} /$ $65 \mathrm{LLTO} / 3 \mathrm{MWCNTS}$ 이고, 전극 복합체는 $600{ }^{\circ} \mathrm{C}$ 에서 5 $\min$ 동안 SPS 공정에 의해 소결되었다. (Fig. 6a) 전고 상 전지 제작을 위해 사용된 고체 전해질은 전극 복합체 와 계면 안정성을 증가 시키기 위해서 비정질계 $\mathrm{LIPON}$ 을 전극 복합체 위에 PVD 공법을 이용하여 증착하였다. (Fig. 6d) 상대 전극으로 $\mathrm{Li}$ 금속을 사용 전고상 전지를 제작 전기화학 평가를 진행한 결과 $\mathrm{LCO} / \mathrm{LLTO} /$ MWCNTs 전극 복합체는 $80{ }^{\circ} \mathrm{C}$ 에서 $0.05 \mathrm{C}$ 의 전류 밀도 에서 $0.3 \mathrm{mAh} \mathrm{cm}$ 의 방전 용량을 나타냈다. (Fig. $6 c-a$ and $6 c-b)$ 또한, 10 사이클 후에도 전극과 전해질 계면에서 안정성 및 전기화학 반응에 따른 전극 물질이 전해질로 확산되는 않는 것을 확인했다. (Fig. 6b)

다른 연구로 $\mathrm{LCO} / \mathrm{Li}_{2.2} \mathrm{C}_{0.8} \mathrm{~B}_{0.2} \mathrm{O}_{3}$ 고체 전해질과 전극 복합체 제작하기 위해서 SPS 공정을 사용했다. ${ }^{34}$ $\mathrm{Li}_{2,2} \mathrm{C}_{0.8} \mathrm{~B}_{0.2} \mathrm{O}_{3}$ 고체 전해질은 상온에서 $1 \times 10^{-6} \mathrm{~S} \mathrm{~cm}^{-1}$ 를 가졌지만, 전고상 전지는 $60{ }^{\circ} \mathrm{C}$ 의 정전류 $10 \mu \mathrm{A} \mathrm{cm}^{-2}$ 에서 $120 \mathrm{mAh} \mathrm{g}^{-1}$ 의 초기용량을 나타냈으며, 10 사이클 후에 $100 \mathrm{mAh} \mathrm{g}^{-1}$ 을 유지했다. 이런 용량 저하는 반복되 는 전극의 팽창과 수축으로 인한 전극과 고체 전해질 계 면에서 안정성 저하로 인한 것이라 판단했다. SPS 공정 으로 제조된 전고상 전지의 우수한 전기 화학적 성능은 $\mathrm{Li}_{2,2} \mathrm{C}_{0.8} \mathrm{~B}_{0.2} \mathrm{O}_{3}$ 고체 전해질과 $\mathrm{LCO}$ 계면에서 접촉 저항이 낮기 때문에 얻어진 것이며, 이번 연구를 통해 전극과 전 해질 사이의 계면은 전고상 전지가 가지는 성능을 향상시 키기 위해서 중요한 요소라고 제안했다.

최근 $\mathrm{SPS}$ 공정은 $\mathrm{Na}_{3} \mathrm{~V}_{2}\left(\mathrm{PO}_{4}\right)_{3} / \mathrm{Na}_{3} \mathrm{Zr}_{2} \mathrm{Si}_{2} \mathrm{PO}_{12} /$ $\mathrm{Na}_{3} \mathrm{~V}_{2}\left(\mathrm{PO}_{4}\right)_{3}(\mathrm{NVP} / \mathrm{NZSP} / \mathrm{NVP})$ 셀을 기반으로 하는 세 라믹 고밀도 $\mathrm{Na}$ 이온 전지 (작동 온도: $200{ }^{\circ} \mathrm{C}$ )를 제조하 는데 처음으로 사용되었다. ${ }^{35)} \mathrm{Na}_{4} \mathrm{~V}_{2}\left(\mathrm{PO}_{4}\right)_{3}$ (음극에서 교 환 된 $1 \mathrm{Na}^{+}$)은 $\mathrm{NaV}_{2}\left(\mathrm{PO}_{4}\right)_{3}$ (양극에서 교환 된 $\mathrm{Na}^{+}$로 산 화 될 수 있기 때문에 $\mathrm{Na}_{3} \mathrm{~V}_{2}\left(\mathrm{PO}_{4}\right)_{3}$ 은 두 전극에서 모두 사용되었으며, 전고체 NVP/NZSP/NVP 셀을 제조하기 위해서 전극에 포함하는 전극 활물질, 고체 전해질 및 카 본 도전제의 함량을 $25 \mathrm{NVP} / 60 \mathrm{NZSP} / 15$ 로 전극 복합체 와 고체 전해질을 층별로 형성 후 SPS 공정을 이용 900
${ }^{\circ} \mathrm{C}$ 에서 소결을 통해 제작하였다. (Fig. 7(a)) 각 전극 내 에 NVP와 NZSP 입자는 높은 분산도를 가졌으며, 전고 상 전지 두 전극 및 고체 전해질의 두께를 Fig. 7(b)에 보 는 것과 같이 전고상 전지가 가지는 전기화학 특성을 가 지 위해서 최적화해 나타냈다. 전고상 전지가 가지는 전 기화학 특성 평가 결과 전고상 전지가 가지는 방전 특성 $\mathrm{C} / 40$ 전류 밀도에서 $6.5 \mathrm{mAh} \mathrm{g}^{-1}$ 가지는 것을 확인했다.

이런 우수한 성능은 30 사이클 충/방전 후에도 NVP, $\mathrm{NZSP}$ 와 카본 첨가제의 우수한 계면 안전성으로 인해 유 지된다는 것을 제시했으며, 이 결과는 전고상 전지 $\mathrm{NVP} /$ $\mathrm{NZSP} / \mathrm{NVP}$ 셀의 에너지 밀도는 $\mathrm{C} / 10$ 에서 약 $1.0 \mathrm{mAh}$ $\mathrm{cm}^{-2}$ 로 이는 소재가 가지는 이론 용량의 $85 \%$ 라는 것을 보고했다.

\section{3. 결론}

본 논문에서는 현재 연구되고 있는 SPS 공정을 통해 제작된 고체 전해질 및 전극 복합체의 특성과 전고상 전 지 성능에 대해서 살펴보았다. 전고상 전지에서 해결해야 할 중요한 과제 중에 하나는 고체 전해질에서 결정 입계 와 전극 복합체에서 전극 활물질과 고체 전해질 계면에서 안정성을 확보하는 것이다. 이와 관련해서 SPS 공정은 단시간 및 상대적으로 낮은 소결 온도에서 고체 전해질 및 전극 복합체에서 치밀한 고체-고체 계면 및 고밀도를 얻기 위한 소결 기술로 제안되었으며, SPS의 이러한 장 점은 소재의 형태와 구조를 유지하면서 우수한 고체-고 체 계면을 형상할 수 있다는 것이다. SPS 공정을 사용 전 고상 전지를 적용을 위한 서로 다른 고체 전해질이 제조 되었으며, 이렇게 합성된 고체 전해질은 전해질 간 계면 에서 접촉이 개선되어 높은 상대 밀도와 이온 전도도를 나타냈다. 또한, 여러 전극 복합체가 SPS 공정에 의해 제 조되었으며, 전고상 전지에 적용 시 안정된 전기화학 성 능을 나타냈다. 그러나 SPS 공정에 의해 전고상 전지가 가지는 성능이 향상되었음에도 불고하고, SPS 공정 전후 의 고체-고체 계면에서 미세 구조에 대한 기본적인 연구 와 이해가 아직까지 부족하고, 결정 입계 (grain boundary)는 여전히 고체 전해질에서 $\mathrm{Li}$ 이온 확산을 방 
해하는 주된 원인 중에 하나이다. 따라서 향후 연구는 다 양한 특성 기술을 사용하여 가능한 계면에서 조성과 구조 를 조사하는데 초점을 맞춰야 한다.

또한, 현재 전고상 전지는 고체 전해질의 두께, 전극 복 합체에서 전극 활물질의 로딩양과 같은 여러 요인들 때문 에 전고상 전지가 가지는 에너지 및 전력 밀도가 아직까 지 상용화를 하기 위해서 낮은 상황이다. 게다가 SPS 공 정에 의해 제조된 전극 복합체는 전기화학 특성을 향상시 키기 위해서 고체 전해질이 가지는 이온 전도도를 증가하 고 전고상 전지 성능을 나타내기 위해서 상온 보다 높은 작동 온도 $\left(60-80{ }^{\circ} \mathrm{C}\right)$ 를 필요로 한다. 따라서, $\mathrm{SPS}$ 공정 에 의해 소결된 고체 전해질은 일반적으로 $1 \mathrm{~mm}$ 보다 크 며, 고체 전해질의 최대 이온 전도도 $\left(5 \times 10^{-3} \mathrm{~S} \mathrm{~cm}^{-1}\right)$ 값을 고려할 때, 고체 전해질의 두께는 전고상 전지가 가 지는 내부 저항을 최소화 하고, 상온에서 작동 가능하며, 기존의 리튬 이온 전지 기술과 경쟁할 수 있는 에너지 밀 도를 가능하게 하기 위해서 최대한 얇게 제조 되어야 한 다. 또한, SPS 공정에 의해 제작된 전극 복합체에서 전 극 활물질의 로딩양은 단지 15 30\%이며, 이는 전형적인 리튬 이온 전지 $(90 \%)$ 보다 횔씬 적은 양이기 때문에 전 극 복합체에 전극 활물질의 증가 및 우수한 이온 전도도 를 가지는 고체 전해질를 확보하는 연구가 추후 필요할 것이다.

\section{참고문헌}

1. J.M. Tarascon and M. Armand, "Issues and challenges facing rechargeable lithium batteries," Nature 414 359-367 (2001).

2. J.B. Goodenough and Y. Kim, "Challenges for rechargeable Li batteries," Chem. Mater. 22 583-603 (2010).

3. X.B. Cheng, R. Zhang, C.Z. Zhao, and Q. Zhang, "Toward safe lithium metal anode in rechargeable batteries: a review," Chem. Rev. 117 10403-20473 (2017)

4. A. Manthiram, X. Yu, and S. Wang, "Lithium battery chemistries enabled by solid-state electrolytes," Nat. Rev. Mater. 216103 (2017).

5. Y.S. Hu, "Batteries: getting solid," Nat. Energy 1 16042 (2016).

6. J. Schnell, T. Günther, T. Knoche, C. Vieider, L.
Köhler, A. Just, et al., All-solid-state lithium-ion and lithium metal batteries - paving the way to large-scale production, J. Power Sources 382 160175 (2018).

7. J.C. Bachman, S. Muy, A. Grimaud, H.H. Chang, N. Pour, and S.F. Lux, "Inorganic solid-state electrolytes for lithium batteries: mechanisms and properties governing ion conduction”, Chem. Rev. 116 140-162 (2016).

8. Y. Meesala, A. Jena, H. Chang, and R.S. Liu, "Recent advancements in Li-ion conductors for all-solidstate Li-ion batteries," ACS Energy Lett. 2 27342751 (2017).

9. A. Mauger, M. Armand, C.M. Julien, and K. Zaghib, "Challenges and issues facing lithium metal for solidstate rechargeable batteries," J. Power Sources 353 333-342 (2017).

10. B. Wu, S. Wang, W. Evans, Z.D. Deng, J. Yang, and J. Xiao, "Interfacial behaviors between lithium ion conductors and electrode materials in various battery systems," J. Mater. Chem. 4 15266-15280 (2016).

11. R. Chen, W. Qu, X. Guo, L. Li, and F. Wu, "The pursuit of solid-state electrolytes for lithium batteries: from comprehensive insight to emerging horizons", Mater. Horiz. 3 487-516 (2016).

12. Olivier Guillon, J. Gonzalez-Julian, B. Dargatz, T. Kessel, G. Schierning, and J. Räthel, "Fieldassisted sintering technology/spark plasma sintering: mechanisms, materials, and technology developments," Adv. Engineering Mater. 16 830849 (2014).

13. L. Wang, J. Zhang, and W. Jiang, "Recent development in reactive synthesis of nanostructured bulk materials by spark plasma sintering," Int. $J$. Refract. Metals Hard Mater. 39 103-112 (2013).

14. Z.A. Munir, D.V. Quach, and M. Ohyanagi, "Electric current activation of sintering: a review of the pulsed electric current sintering process," J. Am. Ceram. Soc. 94 1-19 (2011).

15. Z.A. Munir, U. Anselmi-Tamburini, and M. Ohyanagi, "The effect of electric field and pressure on the synthesis and consolidation of materials: a review of the spark plasma sintering method," J. Mater. Sci. $41763-777$ (2006).

16. E.A. Olevsky, S. Kandukuri, and L. Froyen, "Consolidation enhancement in spark plasma sintering: impact of high heating rates," J. Appl. Phys. 102 114913-114913-12 (2007). 
17. W.D. Richards, L.J. Miara, Y. Wang, J.C. Kim, and G. Ceder, "Interface stability in solid-state batteries," Chem. Mater. 28 266-273 (2016).

18. V. Thangadurai, S. Narayanan, and D.Pinzaru, "Garnet-type solid-state fast $\mathrm{Li}$ ion conductors for $\mathrm{Li}$ batteries: critical review," Chem. Soc. Rev. 43 47144727 (2014).

19. Y. Zhang, F. Chen, T. Rong, Q. Shen, L. Zhang, "Field assisted sintering of dense Al substituted cubic phase $\mathrm{Li}_{7} \mathrm{La}_{3} \mathrm{Zr}_{2} \mathrm{O}_{12}$ solid electrolytes," J. Power Sources 268 960-964 (2014).

20. M. Botros, R. Djenadic, O. Clemens, M. Möller, and $\mathrm{H}$. Hahn, "Field assisted sintering of fine-grained $\mathrm{Li}_{7-3} \mathrm{xLa}_{3} \mathrm{Zr}_{2} \mathrm{Al}_{x} \mathrm{O}_{12}$ solid electrolyte and the influence of the microstructure on the electrochemical performance," J. Power Sources 309 108-115 (2016).

21. M. Huang, T. Liu, Y. Deng, H. Geng, Y. Shen and Y. Lin, "Effect of sintering temperature on structure and ionic conductivity of $\mathrm{Li}_{7-\mathrm{x}} \mathrm{La}_{3} \mathrm{Zr}_{2} \mathrm{O}_{12-0.5 \mathrm{x}},(\mathrm{x}=0.5 \sim 0.7)$ ceramics," Solid State Ionics 204 - 205(3) 41-45 (2011).

22. S.W. Baek, J.M. Lee, T.Y. Kim, M.S. Song, and Y. Park, "Garnet related lithium ion conductor processed by spark plasma sintering for all solid state batteries," J. Power Sources 249 197-206 (2014).

23. M.M. Ahmad, "Enhanced lithium ionic conductivity and study of the relaxation and giant dielectric properties of spark plasma sintered $\mathrm{Li}_{5} \mathrm{La}_{3} \mathrm{Nb}_{2} \mathrm{O}_{12}$, nanomaterials," Ceram. Int. 41 6398-6408 (2015).

24. M.M. Ahmad, "Lithium ionic conduction and relaxation dynamics of spark plasma sintered $\mathrm{Li}_{5} \mathrm{La}_{3} \mathrm{Ta}_{2} \mathrm{O}_{12}$ garnet nanoceramics," Nanoscale Res. Lett. 1058 (2015).

25. Y.X. Gao, X.P. Wang, W.G. Wang, Z. Zhuang, D.M. Zhang, and Q.F. Fang, "Synthesis, ionic conductivity, and chemical compatibility of garnet-like lithium ionic conductor $\mathrm{Li}_{5} \mathrm{La}_{3} \mathrm{Bi}_{2} \mathrm{O}_{12}$," Solid State Ionics 181 1415-1419 (2010).

26. C.M. Chang, Y.I. Lee, S.H. Hong, and H.M. Park, "Spark plasma sintering of $\mathrm{LiTi}_{2}\left(\mathrm{PO}_{4}\right)_{3}$-based solid electrolytes," J. Am. Ceram. Soc. 88 1803-1807 (2005).

27. Z. Wen, X. Xu, and J. Li, "Preparation, microstructure and electrical properties of $\mathrm{Li}_{1,4} \mathrm{Al}_{0,4} \mathrm{Ti}_{1,6}\left(\mathrm{PO}_{4}\right)_{3}$, nanoceramics," J. Electroceramics $22(1-3)$ 342-345 (2009).
28. A. Kubanska, L. Castro, L. Tortet, O. Schäf, M. Dollé, and R. Bouchet, "Elaboration of controlled size $\mathrm{Li}_{1,5} \mathrm{Al}_{0.5} \mathrm{Ge}_{1,5}\left(\mathrm{PO}_{4}\right)_{3}$ crystallites from glass-ceramics," Solid State Ionics 266 44-50 (2014).

29. A. Mei, Q.H. Jiang, Y.H. Lin, and C.W. Nan, "Lithium lanthanum titanium oxide solid state electrolyte by spark plasma sintering," J. Alloys Compd. 486 871-875 (2009).

30. Y. Kobayashi, H. Miyashiro, T. Takeuchi, H. Shigemura, N. Balakrishnan, and M. Tabuchi, "Allsolid-state lithium secondary battery with ceramic/ polymer composite electrolyte," Solid State Ionics 152-153 137-142 (2007).

31. D. Gaelle, V. Virginie, A. Abdelmaula, B. Renaud, T. Laurence, and S. Vincent, "Batteries: the stone age revisited: building a monolithic inorganic lithium-ion battery," Adv. Funct. Mater. 22 2140-2147 (2012).

32. A. Aboulaich, R. Bouchet, G. Delaizir, V. Seznec, L. Tortet, and M. Morcrette, A new approach to develop safe all-inorganic monolithic Li-ion batteries, $A d v$. Energy Mater. 1179-183 (2011).

33. S.P. Woo, S.H. Lee, and Y.S. Yoon, "Characterization of $\mathrm{LiCoO}_{2} /$ multiwall carbon nanotubes with garnettype electrolyte fabricated by spark plasma sintering for bulk type all-solid-state batteries," Compos. B Eng. 124 242-249 (2017).

34. T. Okumura, T. Takeuchi, and H. Kobayashi, "Enhancement of lithium-ion conductivity for $\mathrm{Li}_{2,2} \mathrm{C}_{0.8} \mathrm{~B}_{0.2} \mathrm{O}_{3}$ by spark plasma sintering," J. Ceram. Soc. Japan 125 276-280 (2017).

35. F. Lalère, J.B. Leriche, M. Courty, S. Boulineau, V. Viallet, and C. Masquelier, "An all-solid state NASICON sodium battery operating at $200{ }^{\circ} \mathrm{C}$, $\mathrm{J}$. Power Sources 247 975-980 (2014).

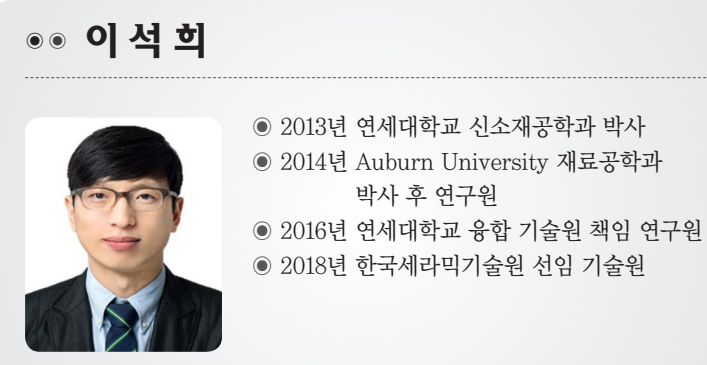

